\title{
Identification of Three Accessory Cell Populations in Human Bone Marrow With Erythroid Burst-promoting Properties
}

David C. Linch, Jeffrey M. Lipton, and David G. Nathan

Division of Hematology-Oncology, the Children's Hospital, and the Dana-Farber Cancer Institute,

Department of Pediatrics, Harvard Medical School, Boston, Massachusetts 02115

\begin{abstract}
Several laboratories have demonstrated a requirement for burst-promoting activity (BPA), a product of $T$ cells, or $T$ cell/ monocyte collaboration in the induction of differentiation of peripheral blood erythroid burst-forming units (BFU-E) in vitro. The physiologic significance of this finding is brought into question by patients with severe mature $T$ cell deficiency who have normal in vivo erythropoiesis. The studies described here were designed to determine whether the burst-promoting effects of marrow $T$ cells and adherent cells are similar to those of peripheral blood, to define whether a third population of marrow cells is capable of production of BPA, and to describe the BPA requirements of immature and mature marrow erythroid progenitors. To that end we prepared adherence- and E-depleted low-density peripheral blood mononuclear cells as a source of BFU-E and demonstrated that their optimal erythropoietin-induced differentiation requires BPA. We then determined that both bone marrow and peripheral blood $T$ cells and monocytes could provide the necessary BPA to induce their erythropoietin dependent differentiation. BPA production by $T$ cells was sensitive to irradiation, but that of the whole bone marrow low-density population was considerably less sensitive. This in itself demonstrated that BPA production in marrow is not $\mathbf{T}$ cell dependent. We further demonstrated a potent, albeit infrequent, third population of BPA-producing marrow cells. These proved to be nonadherent, $\mathrm{E}$ receptornegative, granulocyte antigen-negative, and $\boldsymbol{\gamma}$-Fc receptor-positive. Finally, we separated all of these BPA-producing cells from marrow erythroid progenitors and concentrated the latter into a population in which they comprised $6 \%$ of the cells. With this population we demonstrated that both immature (BFU-E) and mature (colony-forming units [CFU-E]) erythroid progenitors require BPA in addition to erythropoietin to induce them to form erythroid colonies in vitro. These results may explain the normal erythropoiesis found in patients with mature $T$ cell deficiency. Though the differentiation of both BFU-E and CFU-E requires BPA, this need can be met by a special class of nonadherent, radioresistant, $E$ receptor-negative, granulocyte antigen-negative, and $\boldsymbol{\gamma}$-Fc-positive cells.
\end{abstract}

\section{Introduction}

The fine regulation of erythrocyte production is controlled by the hormone erythropoietin, which induces proliferation and

Dr. Linch is a recipient of a British Medical Research Council Travelling Fellowship.

Received for publication 14 May 1984 and in revised form 7 December 1984

J. Clin. Invest.

(C) The American Society for Clinical Investigation, Inc.

0021-9738/85/04/1278/07 $\$ 1.00$

Volume 75, April 1985, 1278-1284 differentiation of mature erythroid progenitor cells (erythroid colony-forming units [CFU-E] $]^{1}$ ) and erythroblasts. The levels of erythropoietin are inversely proportional to the quantity of available oxygen in the blood and are thus related in an inverse manner to the hemoglobin concentration. The replication of immature erythroid progenitors (erythroid burst-forming units [BFU-E]) in vivo is, in contrast, not influenced greatly by erythropoietin (1). In fact, the early proliferative phase of colonies derived from BFU-E in vitro, while responsive in part to erythropoietin (2), mainly depends on the presence of a family of glycoproteins defined as burst-promoting activity (BPA) (3). The source of BPA for human BFU-E-derived colony formation has stimulated much interest. In 1978 Nathan and colleagues (4) demonstrated that peripheral blood $\mathrm{T}$ cells produce BPA and are required for optimal growth of BFU-E into colonies in vitro. Several laboratories have confirmed and extended these studies (5-7) although others have found that, under appropriate conditions, peripheral blood monocytes (8, 9) and large granular lymphocytes (10) can also provide BPA function. Moreover, monocytes and $\mathrm{T}$ cells may interact synergistically to produce the hormone $(9,11)$. Most studies that demonstrate BPA production by $T$ cells and monocytes and the BPA dependence of BFU-E have used peripheral blood as the source of accessory cells and progenitor cells.

Despite the requirement for $\mathrm{T}$ cells or $\mathrm{T}$ cell collaborations in such in vitro erythropoiesis systems, most patients with severe mature $\mathrm{T}$ cell deficiency do not exhibit erythrocyte aplasia. In addition, when Lipton and colleagues (12) turned their attention to the bone marrow, they were unable to show that the removal of $T$ cells from the marrow reduced the growth of BFU-E as was the case in the blood. It was suggested that either the majority of bone marrow BFU-E were more mature than those in the blood and had lost their requirement for BPA, or that there was another accessory cell within the marrow. Similarly, Linch et al. (13) were also unable to show any burst-enhancing effect when they added bone marrow $T$ cells to monocyte- and $\mathrm{T}$ cell-depleted bone marrow. In neither of these studies was it formally shown that bone marrow $T$ cells produce BPA, though Porter and co-workers had demonstrated that bone marrow-conditioned medium contains BPA (14).

The aims of the present study were threefold: $(a)$ to determine whether the burst-promoting effects of marrow adherent cells and $T$ cells are similar to those of peripheral blood adherent cells and T cells; $(b)$ to identify other populations of cells in the marrow capable of producing BPA; and $(c)$ to separate the bone marrow erythroid progenitors from these accessory cells to determine their intrinsic BPA requirements.

1. Abbreviations used in this paper: $\mathrm{Ad}^{+}$, adherent cells; BFU-E, erythroid burst-forming unit; BPA, burst-promoting activity; CFU-E, erythroid colony-forming unit; $\mathrm{E}^{+}$, cells rosetting with amino-ethylisothiouronium bromide-treated sheep erythrocytes; MoCM, Mo cellconditioned medium 


\section{Methods}

\section{Blood and marrow samples}

Bone marrow was obtained from normal volunteers by aspiration from the posterior iliac crest. Peripheral blood was also taken from the marrow donors.

\section{Cell fractionation procedures}

Peripheral blood. Peripheral blood mononuclear cells (Fig. 1) were prepared by buoyant density separation over Ficoll-Hypaque specific gravity 1.077 . Monocytes were largely removed by two $1-\mathrm{h}$ adherence procedures in $9-\mathrm{cm}$ plastic petri dishes at $37^{\circ} \mathrm{C}$. After the first adherence procedure, the adherent cells $\left(\mathrm{Ad}^{+}\right)$were washed six times in tissue culture medium-fetal calf serum, and then removed by gentle scraping. Between 81 and $94 \%$ of these adherent cells were monocytes. The adherent cell-depleted mononuclear cells $\left(\mathrm{Ad}^{-}\right)$were then further fractionated by rosetting for $1 \mathrm{~h}$ with 2-amino-ethylisothiouronium bromide-treated sheep erythrocytes at $4^{\circ} \mathrm{C}(15)$ followed by another centrifugation over Ficoll-Hypaque. This maneuver removed most of the $T$ cells. The interfacial cells $\left(\mathrm{Ad}^{-} \mathrm{E}^{-}\right)$were washed three times in tissue culture medium-fetal calf serum and used as a source of "target BFU-E." Peripheral blood $\mathrm{T}$ cells $\left(\mathrm{E}^{+}\right)$were recovered from the erythrocyte pellet by hypotonic ammonium chloride lysis.

Bone marrow. Low-density cells were prepared by buoyant density separation over Ficoll-Hypaque specific gravity 1.077 . Adherent cells were removed by adherence to plastic for $1 \mathrm{~h}$ at $37^{\circ} \mathrm{C}$. After extensive washing they were removed from the plastic by gentle scraping. This fraction contained between 52 and $82 \%$ monocytes. The nonadherent cells $\left(\mathrm{Ad}^{-}\right)$were then reacted with the IgM monoclonal antibody TG1 at $4^{\circ} \mathrm{C}$. This antibody binds to all cells of the granulocyte series from the promyelocyte to the granulocyte (16). It also reacts with a proportion of mature monocytes and virtually all "promonocytes" as judged by its staining pattern in acute monocytic leukemias (17). TG1 is an unusual mouse monoclonal antibody in that it avidly binds

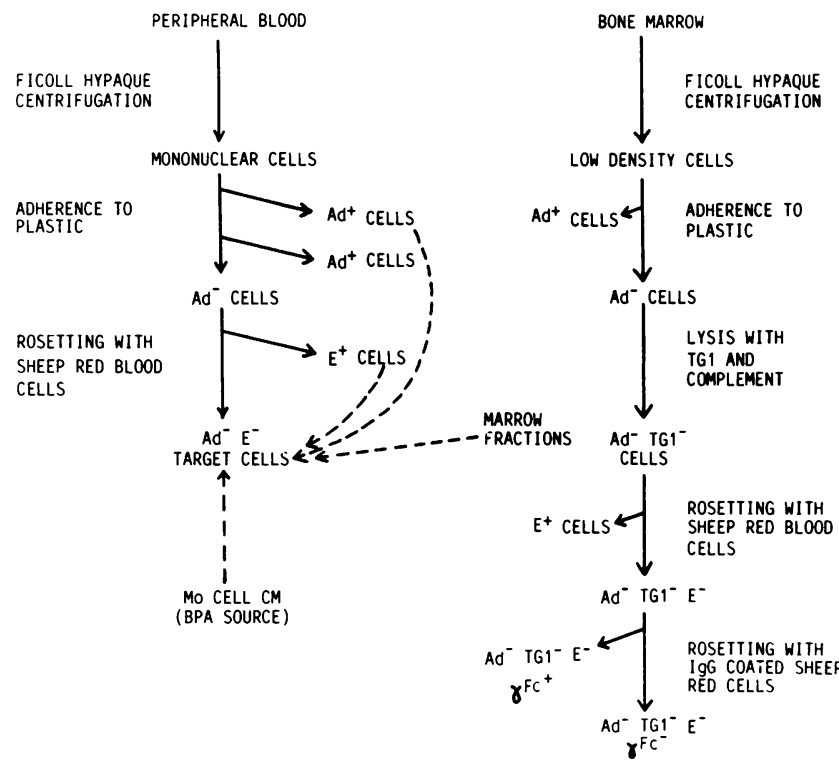

Figure 1. Preparation of blood and marrow cells. Peripheral blood mononuclear cells from which adherent and E-positive cells were removed $\left(\mathrm{Ad}^{-}, \mathrm{E}^{-}\right)$served as target cells at concentrations of $5 \times 10^{4}$ to $10^{5}$ cells $/ \mathrm{ml}$. The interrupted lines show that the cultures were supplemented with either Mo cell-conditioned medium as a source of BPA, $\mathrm{Ad}^{+}$cells (monocytes, usually at $10^{5}$ cells $/ \mathrm{ml}$ ), $\mathrm{E}^{+}$cells $(\mathrm{T}$ cells usually at $2.5 \times 10^{5}$ cells $/ \mathrm{ml}$ ) or the various marrow fractions shown above. The latter were added at cell concentrations described in the text. human complement. Cells binding TG-1 were then lysed by a $45-\mathrm{min}$ incubation at $37^{\circ} \mathrm{C}$ in the presence of autologous serum or rabbit complement (Gibco Laboratories, Grand Island, NY) and $25 \mathrm{U} / \mathrm{ml}$ of DNase (Sigma Chemical Co., St. Louis, MO). The lysis procedure was performed in flat-bottomed Falcon flasks (Flow Laboratories, McLean, VA) to combine the lysis with a further adherence procedure.

$\mathrm{T}$ cells were then virtually completely removed by rosetting with 2-amino-ethylisothiouronium bromide-treated sheep erythrocytes and further centrifugation over Ficoll-Hypaque. The bone marrow $\mathrm{T}$ cells $\left(E^{+}\right)$were recovered from the erythrocyte pellet by hypotonic ammonium chloride lysis. (Rosetting of bone marrow with 2-amino-ethylisothiouronium bromide-treated sheep cells after lysis with TG-1 and complement gives extremely complete $T$ cell and non- $T$ cell separations for reasons that are obscure [13].) In some experiments the $\mathrm{Ad}^{-} \mathrm{TG}$ $1^{-} \mathrm{E}^{-}$marrow cells were further fractionated on the basis of expression of Fc receptors for IgG. The cells were pelleted and incubated for 45 min at $4^{\circ} \mathrm{C}$ with sheep erythrocytes optimally coated with a rabbit anti-sheep erythrocyte IgG fraction (Capell Laboratories, Cochranville, PA) (18), and then centrifuged over Percoll (Pharmacia Fine Chemicals, Piscataway, NJ) specific gravity 1.085. Cells not expressing Fc receptors for $\mathrm{IgG}\left(\mathrm{Fc}^{-}\right)$were recovered from the interface and cells expressing Fc receptors for $\operatorname{lgG}\left(\mathrm{Fc}^{+}\right)$were recovered from the cell pellet by hypotonic ammonium chloride lysis. All cell fractions were washed three times in tissue culture medium-fetal calf serum prior to use.

\section{Immunofluorescent staining}

The $\mathrm{T}$ cell content of different blood and marrow fractions was determined using the pan T monoclonal antibody UCHT1 (T3 equivalent) and indirect immunofluorescence as previously described (19). Stained cells were analyzed by epi fluorescence microscopy.

\section{Detection of monocytes}

The monocyte content of different blood and marrow fractions was determined by nonspecific esterase staining of cytocentrifuge preparations (20).

\section{Erythroid culture studies}

Erythroid colonies were grown in $0.9 \%$ methylcellulose in Iscove's modified Dulbecco's medium (IMDM, Gibco Laboratories) plus 30\% fetal calf serum (Gibco Laboratories) $0.9 \%$ deionized bovine serum albumin (Sigma Fraction V) $10^{-4} \mathrm{M} \beta$-mercaptoethanol, and $1 \mathrm{U} / \mathrm{ml}$ of crude erythropoietin (Connaught Step III) (21). Single red colonies present after $7 \mathrm{~d}$ in culture were scored as CFU-E (marrow only), and larger hemoglobinized colonies found after $14 \mathrm{~d}$ in culture were scored as BFU-E (blood and marrow). Mo cell-conditioned medium (MoCM), kindly provided by Dr. David Golde, was used as a standard source of BPA (22). The effects of conditioned media or cells added to cultures were evaluated by comparisons of colony frequencies after calculation of the standard error of the mean of individual assays. Differences between means were considered significant only if the ranges of standard errors multiplied by 2 did not overlap.

\section{Results}

$B P A$ dependence of peripheral blood BFU-E target cells. Nonadherent non-T cell-containing peripheral blood mononuclear cells were used as a source of target BFU-E. In each experiment this population was cultured at $5 \times 10^{4}$ to $10^{5}$ cells per dish with no added source of BPA or accessory cells, or in the presence of $10 \%$ MoCM as a standard source of potent BPA. Inasmuch as these experiments were performed many times over a span of several months with multiple target cell populations, it became necessary to establish some standard approach to the reporting of results so that experiments performed widely apart in time could be compared. Therefore, we adopted an arbitrary BPA unitage as a standard of comparison. $100 \mathrm{U}$ 
of BPA represents the increment in BFU-E-derived colonies per $10^{5}$ target cells induced by $10 \% \mathrm{MoCM}$. The legends to the figures provide the actual increments for each set of experiments.

Comparison of burst-enhancing activity produced by blood and marrow $T$ cells and monocytes. Blood and marrow $\mathrm{T}$ cells and monocytes were prepared and added to autologous $\mathrm{Ad}^{-} \mathrm{E}^{-}$ peripheral blood mononuclear cells. Monocytes were added at $10^{5}$ cells $/ \mathrm{ml}$ and $\mathrm{T}$ cells at $2.5 \times 10^{5} / \mathrm{ml}$. These numbers were shown in preliminary studies to give close to maximal burst enhancement. Potent BPA was seen in the blood-derived T cell and monocyte fractions. Similar activity was observed from the bone marrow-derived $T$ cells and monocytes (Fig. 2). In each experiment monocyte and $T$ cell fractions were grown alone and any growth of BFU-E-derived colonies was subtracted from the value obtained when these fractions were added to the target BFU-E population. Blood and marrow $T$ cell fractions contained an average 1.1 and 4.0 BFU-E-derived colonies per $10^{5}$ cells plated, respectively. Blood and marrow adherent cell fractions contained 4.0 and 1.6 BFU-E-derived colonies per $10^{5}$ cells plated, respectively.

Detection of a third accessory cell population in the bone marrow. Adherent cell, myeloid cell, and $\mathrm{T}$ cell-depleted marrow preparations cannot be added directly to peripheral blood cells to assess their BPA production. This is because of the high levels of endogenous BFU-E colony growth in this cell fraction (5-10 times the unfractionated low-density marrow cells). Therefore, this marrow preparation must first be irradiated to 1,500 rads at which dose no BFU-E survive (Fig. 3).

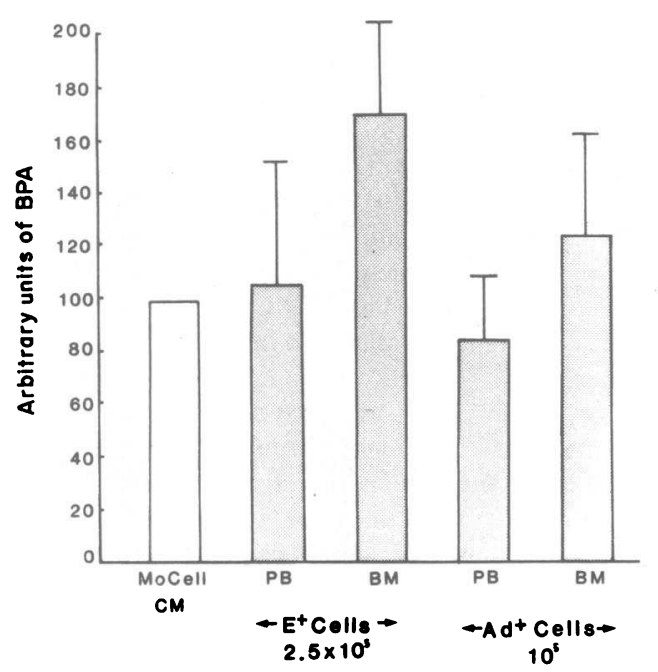

Figure 2. Influence of blood and marrow $\mathrm{T}$ cells and monocytes on growth of BFU-E-derived colonies. $\mathrm{Ad}^{-}, \mathrm{E}^{-}$peripheral blood mononuclear cells at $5 \times 10^{4}$ to $10^{5}$ cells per ml served as a source of target BFU-E to which was added $10 \% \mathrm{MoCM}$. The increment in BFU-E derived colonies induced by this addition of MoCM was arbitrarily assigned a value of $100 \mathrm{U}$ of BPA. In this experiment, the average number of BFU-E-derived colonies without added MoCM was 43 per $10^{5}$ target cells and the average with MoCM was 60 for an increment of $141 \%$. Thus in this experiment $100 \mathrm{U}$ of BPA equals 17 incremental BFU-E-derived colonies per $10^{5}$ target cells. The additions of peripheral blood or bone marrow $\mathrm{E}^{+} \mathrm{Ad}^{+}$cells to these cultures at particular cell concentrations per $\mathrm{ml}$ are shown on the abscissa of the figure. The incremental BFU-E-derived colonies induced by added cells are presented as units of BPA. The error bars represent 1 SEM.

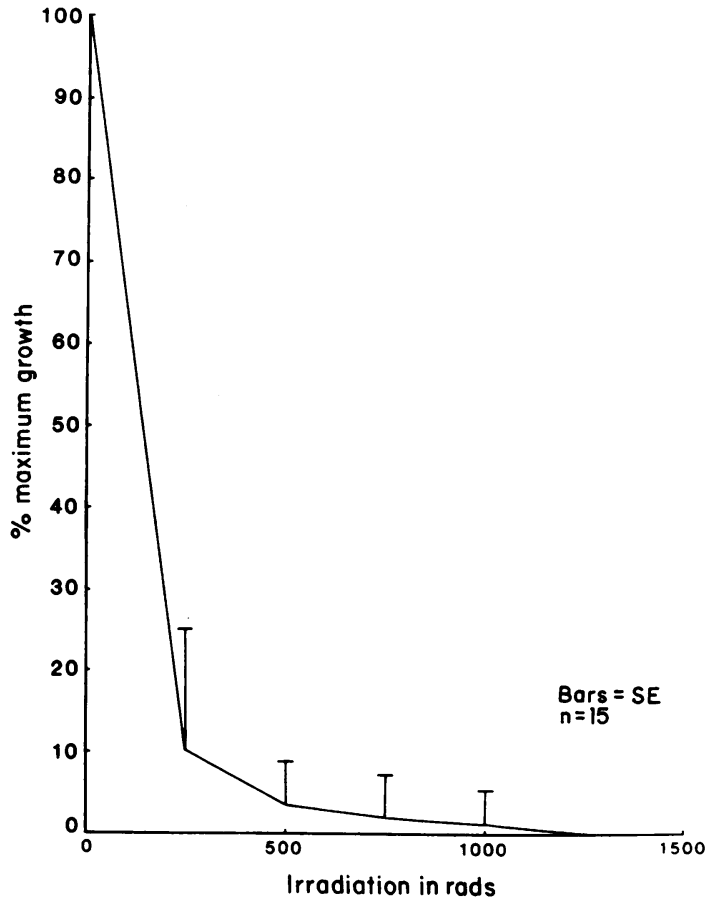

Figure 3. Effect of irradiation on BFU-E growth. Low-density bone marrow cells in Iscove's modified Dulbecco's medium and 10\% fetal calf serum were irradiated at the doses shown at a dose of 500 rads/ min. The cells were then cultured in methylcellulose at $5 \times 10^{4}$ cells/ $\mathrm{ml}$. Growth in the absence of radiation was taken as $100 \%$ of maximum growth.

The irradiation dose-response curves for BPA production by peripheral blood $\mathrm{T}$ cells and low-density bone marrow cells were also determined (Fig. 4). The results were significantly different. $\mathrm{T}$ cell BPA production is radiosensitive with activity reduced by $\sim 70 \%$ at 1,500 rads. Bone marrow BPA production is, by contrast, relatively radioresistant with nearly $90 \%$ activity retained after 1,500 rads. The difference is statistically significant. This clearly shows that $T$ cells are not the major source of BPA production in irradiated low-density cells derived from bone marrow and suggests that 1,500 rads of irradiation to the adherent cell, myeloid cell, and $\mathrm{T}$ cell-depleted marrow might not eliminate BPA production.

In a further series of experiments, different irradiated bone marrow fractions were assessed for BPA (Fig. 5). The lowdensity unfractionated bone marrow cells had potent BPA. So also did the marrow adherent cells indicating that this population of marrow accessory cells is relatively radioresistant. The irradiated marrow $\mathrm{T}$ cells had very little BPA confirming the radiosensitivity shown for blood-derived $T$ cells. Most interestingly, there was potent BPA production by the irradiated and monocyte-depleted and the monocyte and T cell-depleted bone marrow cells when plated at $1.25 \times 10^{5}$ cells $/ \mathrm{ml}$. In one experiment maximal activity was noted down to a cell concentration of $0.125 \times 10^{5}$ cells $/ \mathrm{ml}$. This $\mathrm{Ad}^{-} \mathrm{TG}-1^{-} \mathrm{E}^{-}$fraction contained $<1 \% \mathrm{~T}$ cells $\left(\mathrm{UCHT}^{+}\right)$and $<0.5 \%$ monocytes (nonspecific esterase positive) in each experiment. This experiment indicates that there is a third BPA-producing accessory cell within the bone marrow.

To confirm this finding, the cell number dose-response curve for BPA production was established for $\mathrm{T}$ cells, monocytes, and the non-T cell nonmonocyte marrow cells (Fig. 6). 


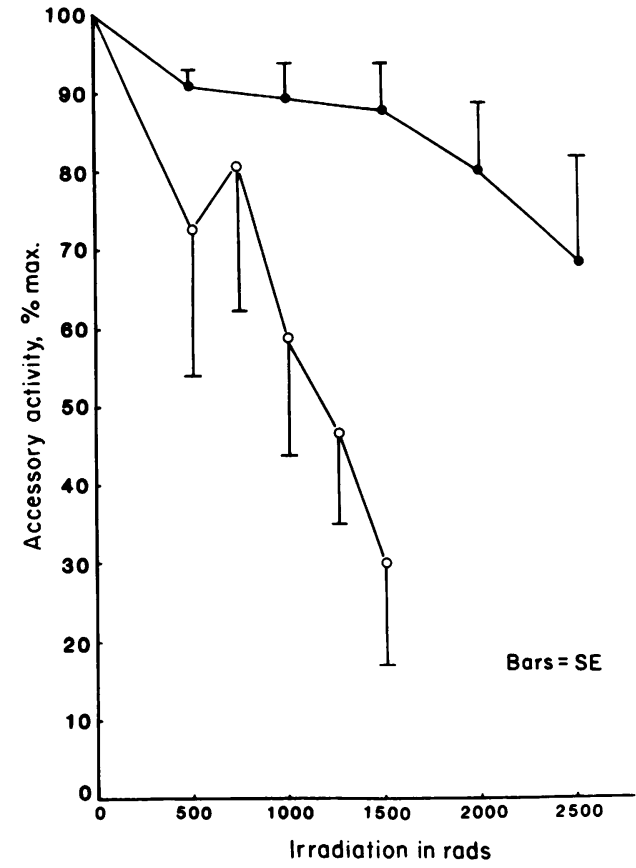

Figure 4. Effect of irradiation on accessory cell function. Peripheral blood $\mathrm{E}^{+}(0)$ and bone marrow low-density cells $(\bullet)$ were suspended at $5 \times 10^{5}$ cells per $\mathrm{ml}$ and irradiated at the doses shown on the abscissa at $500 \mathrm{rads} / \mathrm{min}$. From 2 to $5 \times 10^{5}$ of these irradiated cells were then added to $5 \times 10^{4} \mathrm{Ad}^{-}, \mathrm{E}^{-}$, peripheral blood mononuclear cells to determine their capacity to serve as accessory cells in the stimulation of erythroid colony formation. $100 \%$ accessory cell activity is derived from the influence of the addition of nonirradiated $\mathrm{T}$ cells to the culture. Note that bone marrow cells must be irradiated to a minimum of 1,500 rads (Fig. 3) to eliminate endogenous progenitor cell function before any determination of accessory cell function can be made.

It is evident that $\mathrm{T}$ cell contamination cannot account for the activity in the marrow "third population" as their doseresponse curves are similar. Monocytes may produce more BPA per cell than do $T$ cells or marrow third population cells, but the differences are not significant and this contamination could only account for the "third population" activity if it was at the level of $10 \%$. Monocytes were extensively removed in this study (TG-1 and complement lysis and two adherence procedures). In all experiments no monocyte contamination

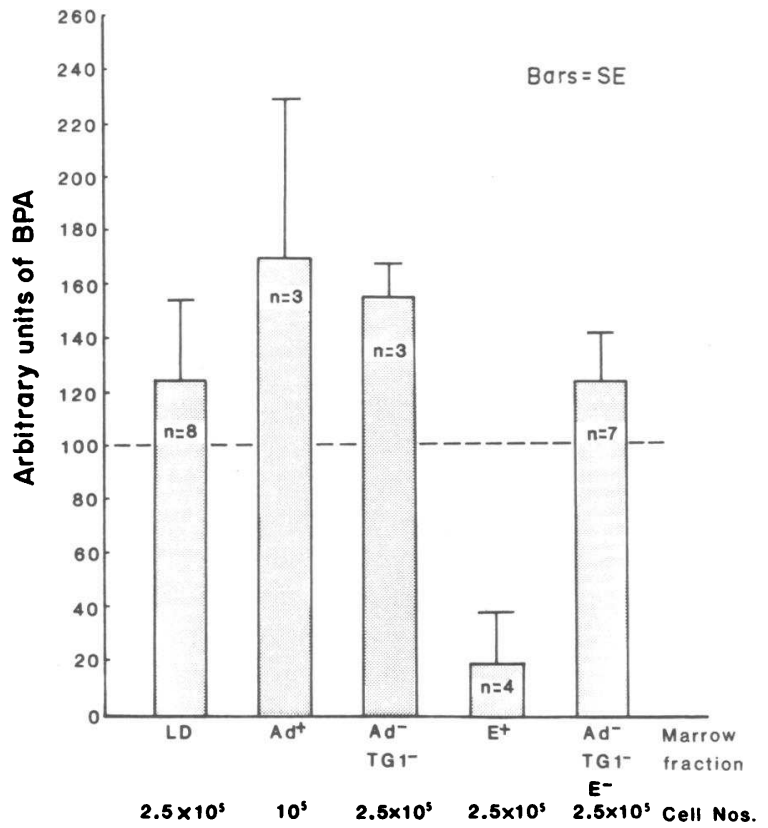

Figure 5. BPA production by different irradiated bone marrow fractions. In this experiment, the average number of BFU-E-derived colonies without added MoCM was 53 per $10^{5}$ target cells, and the average with MoCM was 139 for an increment of $256 \%$. Thus $100 \mathrm{U}$ of BPA represents 86 incremental BFU-E derived colonies per $10^{5}$ target cells. Various marrow cell fractions (each irradiated to 1,500 rads) were added at the concentrations per $\mathrm{ml}$ shown on the abscissa to $5 \times 10^{4} \mathrm{Ad}^{-}, \mathrm{E}^{-}$, peripheral blood mononuclear cells. The effects of additions of these marrow cell fractions on incremental BFU-Ederived colony numbers were measured simultaneously and the results presented as units of BPA, the latter determined from the effects of MoCM. The error bars represent 1 SEM. Note that the irradiation abolishes the BPA activity produced by $T$ cells. Hence the marrow $\mathrm{E}^{+}(\mathrm{T})$ cells had lost nearly all of their stimulatory activity.

beyond one monocyte per 200 cells could be detected in the "third population."

Expression of $F c$ receptors for immunoglobulin $G$ by "third population" marrow accessory cells. In an attempt to further characterize the cell type producing BPA within the "third population" of bone marrow cells, this population was fractionated according to the presence of Fc receptors for immunoglobulin $\mathrm{G}$ (IgG) (Fig. 1). In four experiments $31 \pm 10 \%$ of

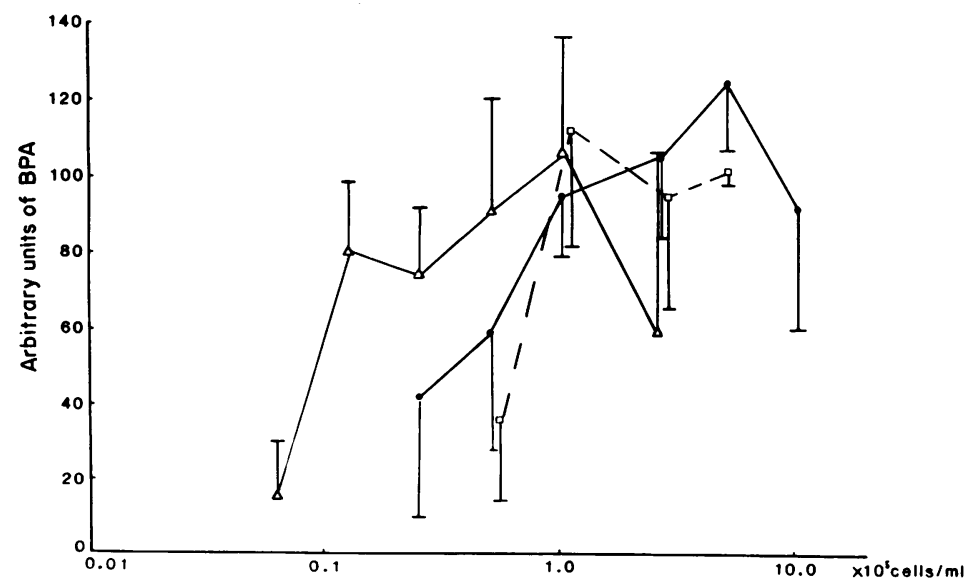

Figure 6. BPA production by monocytes and adherence depleted TG-1 ${ }^{-} \mathrm{E}^{-}$bone marrow cells. The ordinate represents the arbitrary units of BPA (see legend to Fig. 2) produced by varying concentrations of irradiated bone marrow fractions that serve as accessory cells. In this series of experiments, the average number of BFU-E derived colonies without added MoCM was 40 per $10^{5}$ target cells, and the average with MoCM was 66 for an increment of $163 \%$. Thus $100 \mathrm{U}$ of BPA represents 26 incremental BFU-E derived colonies per $10^{5}$ target cells. The concentration of cells added to the target cells $\left(5 \times 10^{4}\right.$ nonirradiated $\mathrm{Ad}^{-}, \mathrm{E}^{-}$, peripheral blood mononuclear cells) is shown on the logarithmic scale on the abscissa. ( $\Delta$ ), Monocytes; ( $\square$ ), adherence depleted $\mathrm{TG}-1^{-} \mathrm{E}^{-}$bone marrow cells; $(\bullet), \mathrm{E}^{+}$cells. 
$\mathrm{Ad}^{-}, \mathrm{TG}-1^{-}, \mathrm{E}^{-}$cells expressed Fc receptors for IgG. In each experiment there was more BPA produced per cell in the $\mathrm{Fc}^{+}$ fraction compared with the $\mathrm{Fc}^{-}$fraction (Fig. 7). In two experiments there was detectable BPA production in the $\mathrm{Fc}^{-}$ fraction, but in two other experiments there was virtually none. This suggests that the majority of third population accessory cells express $\mathrm{Fc}$ receptors for $\mathrm{IgG}$ but that this expression is weak. Morphologically this population consisted of lymphocytes of all sizes and some larger ill-defined mononuclear cells.

BPA dependence of marrow erythroid progenitor cells. The bone marrow fractionation procedure led to a marked enrichment of erythroid progenitor cells within the nonadherent, nonmyeloid, non-T cell, Fc-negative population (Table I). The enrichment provided a population of cells of which $\sim 6 \%$ were erythroid progenitors. This population, largely depleted of three accessory cell populations, was then plated at $10^{4}$ cells/ $\mathrm{ml}$, with and without MoCM, to determine the BPA requirement of these partially purified bone marrow-derived erythroid progenitor cells. This effect of the MoCM was contrasted with its effects on the differentiation of unfractionated low-density marrow cells plated at $10^{5}$ cells per dish. The results of four experiments are shown in Fig. 8. It is apparent that BPA is required for the optimal growth of both bone marrow BFU-E and CFU-E if the latter are sufficiently separated from accessory cells capable of endogenous BPA production.

\section{Discussion}

This study shows that bone marrow $\mathrm{T}$ cells and monocytes are as effective at producing BPA as those in the peripheral

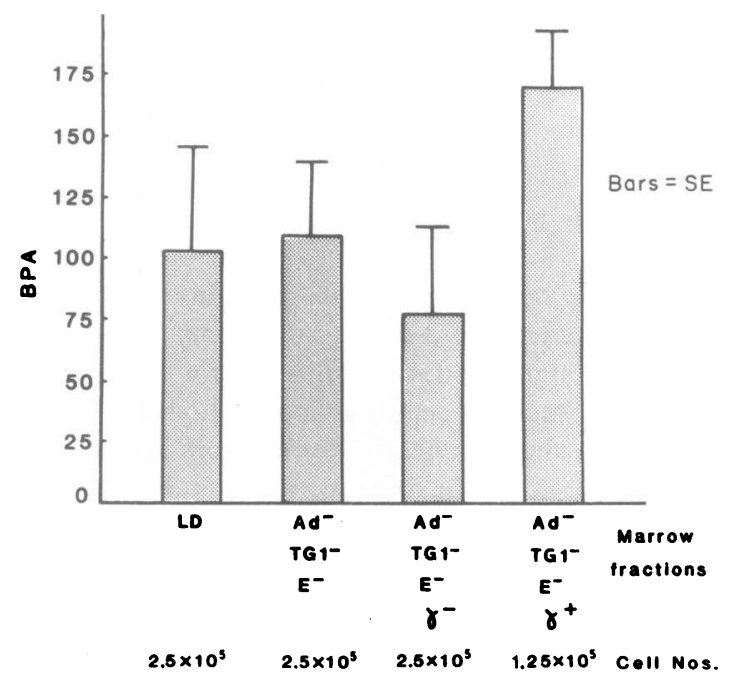

Figure 7. Fractionation of $\mathrm{AD}^{-} \mathrm{TG}^{-} 1^{-} \mathrm{E}^{-}$bone marrow into $\gamma-\mathrm{Fc}^{+}$ and $\gamma-\mathrm{Fc}^{-}$fractions. The bar graph represents a further fractionation of low-density (LD) bone marrow cells into $\mathrm{Ad}^{-}, \mathrm{TG}^{-} 1^{-}, \mathrm{E}^{-}, \gamma-\mathrm{Fc}^{-}$, or $\gamma-\mathrm{Fc}^{+}$fractions. All of these irradiated fractions were added at the cell numbers shown on the abscissa to $1-\mathrm{ml}$ cultures containing 5 $\times 10^{4}$ nonirradiated $\mathrm{Ad}^{-}, \mathrm{E}^{-}$, peripheral blood mononuclear cells as target cells. In this series of experiments, the average number of BFU-E-derived colonies without added MoCM was 38 per $10^{5}$ target cells, and the average with MoCM was 179 for an increment of $472 \%$. Thus $100 \mathrm{U}$ of BPA represents 141 incremental BFU-Ederived colonies per $10^{5}$ target cells. Note that the $\gamma$ - $\mathrm{Fc}^{+}$fraction is clearly more stimulatory than the others even though it is present at one half of the cell concentration.
Table I. Erythroid Progenitors in Different Marrow Fractions $10^{5}$ Cells

\begin{tabular}{lcc}
\hline & CFU-E* & BFU-E* \\
\hline Unfractionated low-density & & \\
marrow cells & $137 \pm 50$ & $78 \pm 22$ \\
$\mathrm{Ad}^{-} \mathrm{TG}-1^{-} \mathrm{E}^{-} \mathrm{Fc}^{-}$ & $3,300 \pm 1,651$ & $2,100 \pm 1,224$ \\
$\mathrm{Ad}^{-} \mathrm{TG}-1^{-} \mathrm{E}^{-} \mathrm{Fc}^{+}$ & $47 \pm 49$ & $18 \pm 23$
\end{tabular}

$\mathrm{Ad}^{-} \mathrm{T}-\mathrm{GI}^{-} \mathrm{E}^{-}$, Nonadherent, nonmyeloid, non-T cell fraction.

* Mean \pm standard error.

blood. Blood and marrow $\mathrm{T}$ cells are in other ways distinct and the same may also be true for monocytes. Whereas the majority of peripheral blood $\mathrm{T}$ cells are of the help/inducer phenotype, the majority of bone marrow $\mathrm{T}$ cells are of the cytotoxic/suppressor phenotype (23). The demonstration in this study that bone marrow $T$ cells are potent producers of BPA is in accord with the finding that peripheral blood $T$ cells of both subsets produce BPA $(24,35$ and unpublished observations).

BPA production by $T$ cells is radiosensitive whereas monocyte BPA production is relatively radioresistant. In a previous study, T cell production of BPA was shown to be sensitive to a radiation dose of 500 rads (4). We here show that over $70 \%$ of the BPA activity produced by nonstimulated $T$ cells is eliminated by only 1,500 rads, a dose that completely ablates erythroid colony growth from blood or marrow. (125 rads

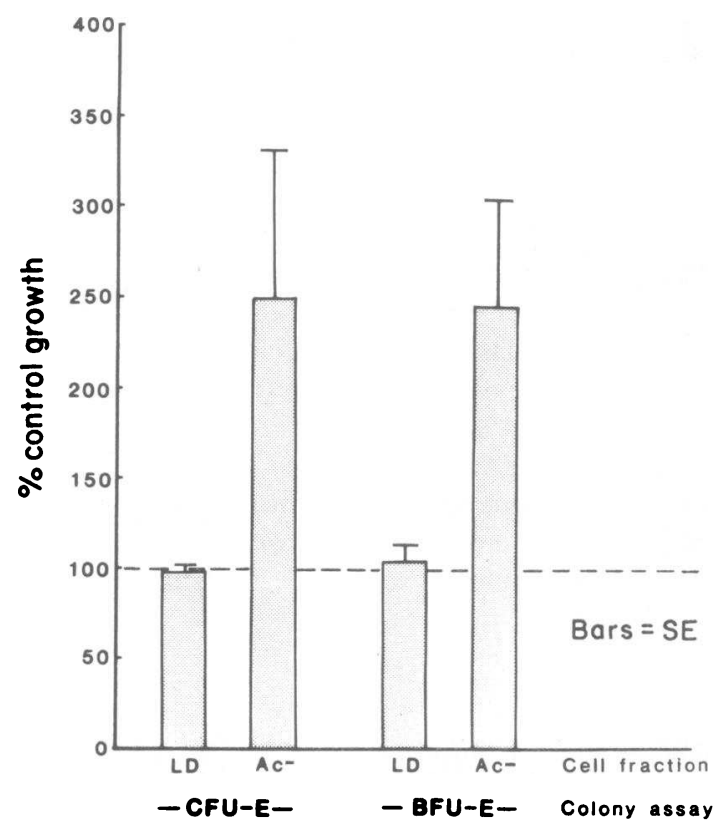

Figure 8. Effects of addition of MoCM to unfractionated and accessory cell-depleted marrow progenitor cells. The influence of MoCM on nonirradiated bone marrow erythroid progenitor cells is shown for two different marrow preparations. Low density (LD) cells represent the cells collected from Ficoll-Hypaque separations whereas $\mathrm{AC}^{-}$ (accessory depleted cells) are $\mathrm{Ad}^{-}, \mathrm{E}^{-}, \mathrm{TG}-1^{-}, \mathrm{Fc}^{-}$marrow cells. The latter procedures lead to the concentration of progenitor cells found in Table I. Note that the addition of MoCM to unfractionated marrow cells does not stimulate the growth of either CFU-E or BFU$\mathrm{E}$ but markedly stimulates both forms of colony formation when accessory cells are depleted. 
produce a $50 \%$ kill of BFU-E, a half value similar to the 113 rads defined by Tepperman et al. [25] for human CFU-E grown in plasma clot.) Because the residual $30 \%$ contribution of BPA by $\mathrm{T}$ cells would be undetectable in most experiments, marrow irradiated to 1,500 rads can be utilized to investigate non-T cell-derived sources of BPA.

Using this technique, we have shown that there is a third population of BPA producing accessory cells within the marrow. It is the presence of these cells, we believe, which has contributed to the previous failures to demonstrate a BPA requirement for bone marrow erythroid progenitor cells $(12,13)$. Most of the cells in this "third population" of marrow cells appear to be lymphoid and most express Fc receptors for IgG. The precise lineage of these cells is still to be defined because the paucity of bone marrow cells available after such extensive fractionation procedures makes further studies difficult. Meytes et al. (26) have described $\mathrm{E}^{-}$radioresistant nonadherent cells in the peripheral blood that produce BPA, but only when they are stimulated with PHA. Kanamura and associates (27) detected a nonadherent radio and anti- $\theta$-resistant cell in murine marrow, spleen and thymus. These cells were capable of inducing BFUE colony formation only when added in very large numbers to the marrow cells of germ-free mice (27). Recent evidence suggests that both endothelial cells (28) and platelets (29) generate factors that can induce BPA-like function in erythroid culture systems. How these cells and the large granular lymphocytes that also appear to produce BPA (10) relate to the marrow accessory cells that we describe is presently unclear. Hematopoietic inducers of different molecular configuration have been shown to have similar hematopoietic colony stimulating functions (30-32). It is possible that the BPA activity produced by $T$ cells, monocytes, and the third population of cells reported here may be derived from the expression of lineage specific genes.

Which of the bone marrow accessory cell populations is the most important source of BPA in vivo is difficult to determine. Monocytes and the "third population" of $\mathrm{Fc}^{+}$ accessory cells account for $<2 \%$ of low-density marrow cells and $T$ cells probably account for $<5 \%$ in undiluted samples. Although numerically greater, $\mathrm{T}$ cells are not the major source of bone marrow-derived BPA as is shown by the radioresistance of bone marrow BPA production. This could explain the normal erythropoiesis seen in totally $\mathrm{T}$ cell-deficient severe combined immunodeficiency.

Peripheral blood $\mathrm{T}$ cells and monocytes interact in the production of BPA $(9,11)$. T cells appear to produce a lymphokine, which enhances monocyte BPA production (9). Monocytes may produce a factor that stimulates BPA production by endothelial cells (33). In separate studies we have shown that BPA of $\mathrm{T}$ cell, as well as monocyte, origin acts directly on highly purified erythroid progenitor cells (34). It is not yet known whether the third population of marrow accessory cells produce directly acting BPA, or to what extent if any they interact with other accessory cells and therefore act indirectly.

Finally, this study clearly shows that both BFU-E and CFU-E are dependent on BPA for optimal growth. Though it is generally assumed that BPA dependence is lost with maturation along the erythroid pathway (3), this must clearly occur after the CFU-E stage of differentiation. Golde and colleagues (22) have also been able to demonstrate a BPA requirement for BFU-E and CFU-E by using unfractionated marrow cells grown under low-serum conditions. The low serum reduces endogenous BPA in the culture system and may also prevent the accessory cells present from producing BPA.

All erythroid progenitor cells thus require BPA for proliferation and differentiation, and at least three populations of bone marrow cells are able to provide this activity. This conservative system affords maximal protection for the maintenance of erythrocyte production. Further delineation of the interactions of this regulatory mechanism will require very highly purified populations of both accessory cells and progenitor cells.

\section{Acknowledgments}

The monoclonal antibodies TG-1 and UCHT1 were kindly provided by Dr. P. C. L. Beverley.

This work was supported by grants from the National Institute of Health and from the Dyson Foundation.

\section{References}

1. Iscove, N. N. 1977. The role of erythropoietin in regulation of population size and cell cycling of early and late erythroid precursors in mouse bone marrow. Cell Tissue Kinet. 10:323-334.

2. Dessypris, E. N., and S. B. Krantz. 1984. Effect of pure erythropoietin on DNA synthesis by human marrow day 15 erythroid burst forming units in short term liquid culture. Br. J. Haematol. 56: 295-306.

3. Iscove, N. N. 1978. Erythropoietin independent stimulation of early erythropoiesis in adult marrow cultures by conditioned media from lectin stimulated mouse spleen cells. ICN-UCLA Symposium on Haemopoietic Cell Differentiation. Mol. Cell Biol. 37-82.

4. Nathan, D. G., L. Chess, D. G. Hellman, B. Clarke, J. Breard, E. Merler, and D. Housman. 1978. Human erythroid burst forming unit: T cell requirement for proliferation in vitro. J. Exp. Med. 147: 324-329.

5. Mangan, K. F. 1982. Regulation of human blood erythroid burst-forming unit (BFU-E) proliferation by T-lymphocyte subpopulations defined by Fc receptors and monoclonal antibodies. Blood. 59: 990-996.

6. Torok-Storb, B. J., P. J. Martin, and H. Hansen. 1981. Regulation of in vitro erythropoiesis by normal $\mathrm{T}$ cells: evidence for two $\mathrm{T}$ cell subsets with opposing function. Blood. 58:171-174.

7. Clarke, B. J., D. G. Nathan, B. P. Alter, B. G. Forget, D. G. Hillman, and D. Housman. 1979. Hemoglobin synthesis in human BFU-E and CFU-E derived erythroid colonies. Blood. 54:805-817.

8. Eaves, C. J., and A. C. Eaves. 1978. Erythropoietin dose response curves for three classes of erythroid progenitors in normal human marrow and in patients with polycythaemia vera. Blood. 52:11961210.

9. Zuckerman, K. S. 1981. Human erythroid burst forming units. Growth in vitro is dependent on monocytes but not $\mathrm{T}$ lymphocytes. J. Clin. Invest. 67:702-709.

10. Pistoia, V., R. Ghio, A. Nocera, A. Leprini, A. Perata, and M. Ferrani. 1985. Large granular lymphocytes have a promoting activity on human peripheral blood erythroid burst-forming units. Blood. 65 : 464-472.

11. Reid, C. D. L., L. C. Baptista, and I. Chanarin. 1981. Erythroid colony growth in vitro from human peripheral blood null cells: evidence for regulation by $\mathrm{T}$ lymphocytes and monocytes. $\mathrm{Br}$. $J$. Haematol. 58:171-174.

12. Lipton, J. M., E. L. Reinherz, M. Kudisch, P. L. Jackson, S. F. Schlossman, and D. G. Nathan. 1980. Mature bone marrow erythroid burst-forming units do not require $\mathrm{T}$ cells for induction of erythropoietin dependent differentiation. J. Exp. Med. 152:350-360.

13. Linch, D. C., D. Boyle, and P. C. L. Beverley. 1982. T cell 
and monocyte requirements for erythropoiesis. Acta Haematol. (Basel). 67:324-328.

14. Porter, P., M. Ogawa, and A. Leary. 1980. Enhancement of the growth of human early erythroid progenitors by bone marrow conditioned media. Exp. Hematol. 8:83-88.

15. Kaplan, M. E., and C. Clark. 1974. An improved rosetting assay for detection of human T lymphocytes. J. Immunol. Methods. 5:131-135.

16. Beverly, P. C. L., D. C. Linch, and D. Delia. 1980. Isolation of human haemopoietic progenitor cells using monoclonal antibodies. Nature (Lond.). 287:332.

17. Linch, D. C., C. Allen, P. C. L. Beverley, A. G. Bynoe, C. S. Scott, and N. Hogg. 1984. Monoclonal antibodies differentiating between monocytic and nonmonocytic variants of AML. Blood. 63: 566-574.

18. Ferrarini, M., L. Moretta, R. Abrile, and M. L. Durante. 1975. Receptors for IgG molecules on human lymphocytes forming spontaneous rosettes with sheep red cells. Eur. J. Immunol. 5:70-76.

19. Beverly, P. C. L., and R. E. Callard. 1981. Distinct functional characteristics of human $\mathrm{T}$ lymphocytes defined by $\mathrm{E}$ rosetting or a monoclonal anti T cell antibody. Eur. J. Immunol. 11:324-336.

20. Yam, L. T., C. Y. Li, and W. H. Crosby. 1971. Cytochemical identification of monocytes and granulocytes. Am. J. Clin. Pathol. 55 283-290.

21. Iscove, N. N., F. Sieber, and K. H. Winterhalter. 1974. Erythroid colony formation in cultures of mouse and human bone marrow: analysis of the requirement for erythropoietin by gel filtration and affinity chromatography on agarose conconvalin A. J. Cell. Physiol. 83:309-320

22. Golde, D. W., N. Bersch, S. G. Quan, and A. J. Lugis. 1980. Production of erythroid potentiating activity by a human T lymphoblastoid cell line. Proc. Natl. Acad. Sci. USA. 77:593-596.

23. Janossy, G., N. Tidman, W. S. Selby, A. Thomas, S. Granger, P. Kung, and G. Goldstein. 1980. Human T lymphocytes of inducer and suppressor types occupy different microenvironments. Nature (Lond.). 288:81-84, 1980.

24. Haq, A. U., J. J. Rinehart, and S. P. Balcerzak. 1983. T-cell subset modulation of blood erythroid burst forming unit proliferation. J. Lab. Clin. Med. 101:53-57.
25. Tepperman, A. D., J. M. Lipton, J. E. Curtis, and E. A. McCulloch. 1974. Erythropoietic colonies in cultures of human marrow. Blood. 44:659-669.

26. Meytes, D., A. Ma, J. A. Ortega, N. A. Shore, and P. P. Dubes. 1979. Human erythroid burst promoting activity produced by PHA stimulated radioresistant peripheral blood mononuclear cells. Blood. 54:1050-1057.

27. Kanamura, A., E. Durban, M. T. Gallagher, S. C. Miller, and J. J. Trentin. 1980. Augmentation of erythroid burst formation by the addition of thymocytes and other myelo-lymphoid cells. J. Cell. Physiol. 104:187-197.

28. Ascensao, J. L., G. M. Vercellott, H. S. Jacob, and E. D. Zanjani. 1984. Role of endothelial cells in human hematopoiesis: modulation of mixed colony growth in vitro. Blood. 63:553-559.

29. Dainiak, N., G. Davies, M. Kalmanti, J. Lawler, and V. Kulkarni. 1983. Platelet derived growth factor promotes proliferation of erythropoietin progenitor cells in vitro. J. Clin. Invest. 71:12061215.

30. Porter, P. N., and M. Ogawa. 1982. Characterization of human erythroid burst-promoting activity derived from bone marrow conditioned media. Blood. 59:1207-1212.

31. Westbrook, C. A., J. C. Gasson, S. E. Gerber, M. E. Selsted, and D. W. Golde. 1984. Purification and characterization of human T-lymphocyte-derived erythroid-potentiating activity. J. Biol. Chem. 259:9992-9996.

32. Nicola, N. A., and M. Vadas. 1984. Hemopoietic colonystimulating factors. Immunol. Today (Amst.). 5:76-80.

33. Zuckerman, K. S., G. Bagby, E. McCall, V. Patel, and D. Goodwin. 1983. Production of human erythroid burst promoting activity by human endothelial cells is stimulated by a monokine. Exp. Hematol. 11:24. (Abstr. 41)

34. Linch, D. C., and D. G. Nathan. 1985. T cell and monocyte derived burst promoting activity act directly on erythroid progenitor cells. Nature (Lond.). In press.

35. Wisniewski, D., A. Strife, M. Wachter, and B. Clarkson. 1985. Regulation of human peripheral blood erythroid burst-forming unit growth by $\mathrm{T}$-lymphocytes and T-lymphocyte subpopulations defined by $\mathrm{OKT}_{4}$ and $\mathrm{OKT}_{8}$ monoclonal antibodies. Blood. 65:456-463. 